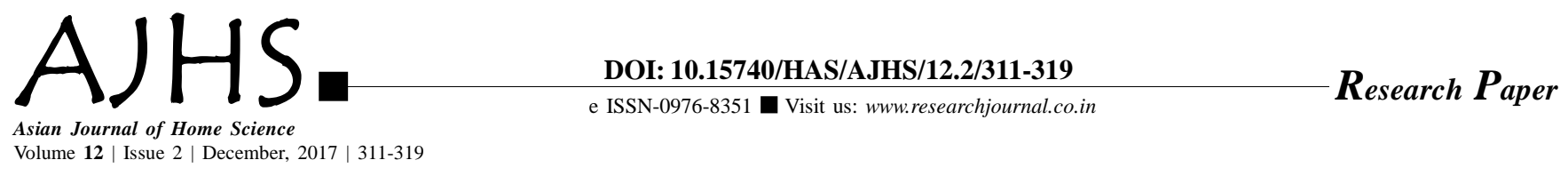

\title{
Women empowerment by entrepreneurship development programmes
}

\author{
YOGITA V. MASUR, VEENA S. JADHAV AND JYOTHI VASTRAD
}

Received: 24.02.2017; Revised: 15.09.2017; Accepted: 01.10.2017

See end of the paper for authors' affiliations

YOGITA V. MASUR

Department of Family Resource

Management, College of Rural Home

Science, University of Agricultural

Sciences, DHARWAD (KARNATAKA)

INDIA

Email : yogitavm7@gmail.com
ABSTRACT : A study on impact of Entrepreneurship Development Programmes on women of Dharwad district was undertaken during 2013-2014. Two taluks, Dharwad and Hubli of the Dharwad district were selected in the study. Women beneficiaries who had undergone Entrepreneurship Development Programmes between 2010-2013 were selected from the records of the respective training institutes i.e. KVK and RUDSETI. Fourty each women beneficiaries from agriculture and non agriculture based training programmes from both the institutions were selected for the data collection. The total sample for the study was 160 women beneficiaries. Agriculture based training programmes for women conducted by KVK during 2010-13 in which 536 women had undergone the training programmes. A total number of women participated were 342 in non- agriculture based training programmes. Agriculture based training programmes conducted for women by RUDSETI during 2010-13 in which total of 489 women had undergone training and non- agriculture based training programmes conducted for women total of 466 women had undergone training. From the findings it was encouraging to see that psychological empowerment has high significance difference after undergoing training and this was followed by social, economic and political empowerment. Women who had undergone training in KVK and RUDSETI had increase in their income after establishing the enterprise. Majority of the women from KVK $(88.88 \%)$ had faced personal constraints like low education level. Women from RUDSETI cent per cent had faced responsibility of performing legitimate household activities. It was observed that women trained in KVK had established Dairy enterprise, preparation of food products and domestic products. Similarly women trained in RUDSETI had established dairy enterprise and tailoring.

KEY WORDS: Empowerment, Entrepreneurship Development Programmes

- HOW TO CITE THIS PAPER : Masur, Yogita V., Jadhav, Veena S. and Vastrad, Jyothi (2017). Women empowerment by entrepreneurship development programmes. Asian J. Home Sci., 12 (2) : 311-319, DOI: 10.15740/HAS/AJHS/12.2/311-319. 